\title{
TRANSILLUMINATING TRISTAN
}

\author{
David Hook \\ King's College London
}

Peter Russell's succinct account of Tristán very effectively covers the main aspects of his role as a character in the Tragicomedia de Calisto y Melibea, noting in a dozen lines the possibility of semantic significance in his name, his perspicacity in spite of his youth, his similarities to the early Pármeno, his loyalty to Calisto, and his effectiveness in a crisis. ${ }^{1}$ Similar points are made by Peter N. Dunn, who treats Sosia and Tristán together, drawing attention to contrasts between them and their predecessors:

Sosia is a stable-lad with mud on his boots, boyish and awkward [...]. Tristán is more experienced and wiser. Again, a contrasting pair, an older and a younger partner, one ready to advise and another willing to learn. [...] More important than the contrast of complementary traits between Tristán and Sosia, is that between this pair of servants and the former pair. Pármeno, after he lost his innocence and his selfrespect, gloried in his readiness to run away [...], and he went wild with joy on inventing some good reason for not exposing himself to risk. [...] Tristán and Sosia, who have, presumably, seen less service and have not until now been personal valets, are sober and reliable. ${ }^{2}$ 
Dunn gives a positive evaluation of Sosia and Tristán; commenting on the conversation in the Tragicomedia when they discuss Sosia's visit to Areúsa, he observes that 'These are the first honest voices that we have heard in a long time, having nothing to conceal, not on the make, not deluded, not driven by fantasies. In this sense they are to be contrasted with everyone (except the earlier Pármeno) and not just with their predecessors. They belong to a world without Celestina and without artificial paradises' (122).

The observations of Russell and Dunn encapsulate the main critical responses to Tristán, commentary on whom is scattered through much other criticism of the work. For Joseph V. Ricapito, for instance, Sosia and Tristán are 'quick-fix supernumeraries'. ${ }^{3}$ He continues: 'The later use of Sosia and Tristán essentially follows the pattern set by Sempronio and Pármeno. They [...] belong to a lower narrative level than Sempronio and Pármeno whose actions are fundamental to the action of the work.' As will be seen, this judgement, whilst obviously valid on one level, may be somewhat more debatable from other points of view, particularly in the case of the Tragicomedia. The relationship between Sempronio/Pármeno and Sosia/Tristán is also examined by Miguel Marciales. ${ }^{4}$ Perceiving a problem with a noble household containing only four servants, he explains this in schematic terms:

Un joven y rico heredero, como Calisto, no podía tener escasamente cuatro servidores: el uno el tipo del criado-confidente corrompido y maleado, el otro lo opuesto, el tipo del criado fiel que va a ser corrompido y maleado, y cuando estos desaparecen y sólo entonces, los reemplazan un mozo de caballos y un page [sic]. Pero es que se trata de tipos esquemáticos, en cierto modo heredados de las comedias latinas, elegíacas y humanísticas, pero hechos más estrictos y en correspondencia geométrica.

According to this, Calisto lives 'en una casa esquemática con un simbólico par de servidores que son geométricamente sustituidos al morir, por otro simbólico par. El criado ya corrompido tiene ya su manceba fija y el criado que va a ser corrompido va también a tener la suya.' In the accompanying diagram, Marciales links Sosia with Sempronio, and Pármeno with Tristán, and places these pairs in a relationship with Elicia and Areúsa respectively. There are some 
problems here, for Sosia is sexually captivated by Areúsa not Elicia, though the latter indeed knows about him (527), and he knows a suspicious amount about her (516). Tristán may possibly have an established amorous relationship, as we shall see; but it is not with Areúsa, for whom, in the Tragicomedia, he professes scorn ('marcada ramera', 563; 'malvada hembra', 'arufianada muger', 564). A simple equivalence of Sosia/Sempronio and Tristán/Pármeno is not appropriate either, since, as already noted, significant contrasts as well as points of similarity exist between the servants.

This point is well made in what is probably the longest single commentary on Tristán, that by María Rosa Lida de Malkiel, who studies his role and character in the text as a whole in her examination of the servants in Celestina. She relates him to Pármeno, but with important reservations: 'Se asemeja a Pármeno en edad y agudeza, pero estas notas, combinadas con las circunstancias en que actúa, determinan reacciones distintas y aun opuestas a las de Pármeno [...] Tiene la agudeza pero no el resentimiento de Pármeno' ${ }^{5}$ There are, however, problems with her approach, since it is based on a reading of Tristán's role in the Tragicomedia and does not take account of modifications made during the change from the sixteen-act to the twenty-one-act text. It also contains some questionable interpretations; thus she notes that Sosia's admiration inspires Tristán with so much self-confidence that it becomes 'temeridad' in offering to climb the ladder with Calisto (615), but at this point Sosia has expressed no admiration for Tristán whatsoever, so that this explanation has no textual basis.

A global interpretation of any character on the basis of the final state of the twenty-one-act version is, of course, from one point of view an appropriate critical approach: this, after all, is the basis on which most readers will have proceeded on any but their first reading of the text from the first publication of the Tragicomedia. It may prove fruitful, however, in the case of Tristán to follow an alternative approach of examining the emergence of the character as the narration proceeds, and charting any changes which occur in the various phases in the development of Celestina. Otherwise, what is offered is a monolithic interpretation in which comments or actions from later in the text or added in a later stage of the work are allowed to establish a set of defining characteristics which do not, perhaps, always accord with evidence from earlier in the sequence of events or from previous states of the text. As Peter Russell reminds 
us, the Comedia 'es una obra autónoma que tuvo (y todavía tiene) su propia vida de libro' (12).

In the Comedia, Tristán is introduced first in Aucto XIII, when Calisto calls for his servants: '¡Tristanico! ¡Moços! ¡Tristanico! ¿Leuanta[te] de ay!' ${ }^{6}$ In the edition by Peter Russell, the text reads '¡Moços! ¡Tristanico! ¡Levantá de ay!' (488), omitting the first 'Tristanico' offered by the earliest editions. If this is regarded as an anticipatory duplication produced in the transmission of the text, then its editorial omission is justifiable, but there remains a literary problem. In the early printed editions, Calisto's first word calls an entirely new character; in Russell's text, he appears to first call his servants, without being much concerned which of them responds, and only then calls Tristán. Even here, Tristán is still, of course, a wholly new introduction, and since Calisto does not appear to have got out of bed, it is difficult to assume that he has simply stumbled across Tristán while looking for a servant. That Calisto should now call a character never previously mentioned has been considered an artistic weakness by James R. Stamm. ? The technique of introducing a new character with his being called by name by Calisto is, however, the one previously used for Sempronio (213) and Pármeno (239). More important, perhaps, is the fact that, since he is addressed with a diminutive by his master, the first reference to Tristán in the text is also the first evaluation of him; but its significance is not immediately clear, for, despite María Rosa Lida de Malkiel's confident statement that 'entra en escena con el diminutivo que indica su edad' (614), the implications of that diminutive could be affective, physical, or statusrelated as well as chronological, and at this stage the reader is given no further information with which to interpret it.

The question of Tristán's being held in special affection by Calisto need not, I think, detain us overlong; Calisto's egocentricity and general lack of regard for others rapidly enable us to treat this possibility as unlikely: a judgement later confirmed by his rough rejection of Tristán's offer to climb the ladder, 'Quedaos, locos' (499). (Possible motives for his sudden onset of apparent concern for Tristán and Sosia outside the garden later are considered below). The greater likelihood of an age-related, rather than any other, explanation of Tristán's diminutive appears to be supported by another reference later in the Comedia to his relative youth: while listening to Calisto and Melibea making love in the garden, he calls himself a mochacho (502). It is interesting, however, that the diminutive is used only by 
his master $(488,495)$, while Sosia, on the other hand, consistently addresses him with the simplex 'Tristán' $(499,502),{ }^{8}$ as does Lucrecia (576). This raises the question of whether his youth is the only factor to be taken into account, or whether the situation is complicated by his status in the household. In the absence of a full study of contemporary onomastic practice, it is difficult to offer much specific evidence, but there are indications from other fifteenth-century Spanish sources that diminutives were routinely applied to servants. An extreme literary manifestation of this is provided by the Arcipreste de Talavera's hysterical woman, who utters diminutives and curses almost simultaneously to her household:

¡Moças, fijas de putas, venid acá! ¿Dónde estades, moças? ¡Mal dolor vos fiera! ¿Non podes rresponder 'Señora'? ¡Ha, agora, landre que te fiera! $Y$ ¿dónde estauas? [...] Pues, corre en vn punto, Juanilla, ve a casa de mi comadre, dile sy vieron una gallyna rruvia de una calça bermeja. Marica, anda, ve a casa de mi vezina, verás si pasó allá mi gallina rruvia. Perico, ve en un salto al vicario del arçobispo [...] Alo[n]sillo, ven aca [...] Llámame, Juanillo, al pregonero que $\mathrm{m}[\mathrm{e}] \mathrm{la}$ pregone por toda esta vezindad!

Evidence from literary texts is, of course, subject to various reservations, and a preferable source is contemporary archival materials in order to come as close to social reality as possible. Fernando González Ollé's examination of the diminutive includes its use in the Cuentas de Gonzalo de Baeza, the treasurer of Queen Isabel. ${ }^{10}$ He concludes that the frequent use of diminutives to designate servants represents 'la denominación con que los correspondientes sujetos (de la mayoría consta expresamente su condición de servidores reales [...]) eran conocidos en la corte' (138-139), and that these diminutive forms 'han de considerarse como sus denominaciones habituales' (104). The accounts of Gonzalo de Baeza give, however, no indication of the age of the servants thus designated. In this respect, the following extract from the Inquisition documents relating to the trial of Mayor González in 1511 is more revealing:

Preguntada que moços e moças a avido en la dicha casa [...] dixo que a la dicha su hermana Elena, e Maria e Ysabel, esclabas, que son defuntas, e Catalina, 
que es de Argamasilla, hija de Diego de la Villa [...], vna Pasculina, conversa, de hedad de doze años, fija de Juan Sanches, vesino de Malagon, e Françisca, donzella, fija deste testigo, que es de hedad de diez e seys años [...]. E que agora tienen en casa dos moços, el vno se llama Miguelito, hijo de Miguel Rodrigues, vesino de Las Casas, e Juanico, de diez e ocho años, hijo de Juan Moños que vibe en Las Casas. ${ }^{11}$

Here, Pasculina, aged twelve, Miguelito, of unspecified age, and the eighteen-year-old Juanico all have diminutives; whether the latter's may have been dictated to some extent by the need to differentiate him from his father Juan is a moot point, since the latter was not resident in the establishment concerned. Clearly if this household and that of Queen Isabel were typical, servants might be identified with a diminutive instead of their actual name as a matter of course even at the age of eighteen. The overtones of the diminutive 'Tristanico' might therefore have been a source of some initial uncertainty for contemporary readers; but on balance the age-related explanation should probably be regarded as paramount in view of the later explicit statement in the text about Tristán's youth (though his precise age is not specified), and since he is the only one of Calisto's servants to be treated thus.

When Calisto first calls Tristán, however, we are faced simply with the diminutive, and therefore with an unresolved problem of evaluation. Tristán's response to his master's call is immediate, though, and the ensuing scene is of some importance in establishing his character. Ordered by Calisto to fetch Pármeno and Sempronio, he is unable to find them, and is at once instructed first to open the windows to ascertain the time of day, and then immediately to close them again and to leave Calisto to sleep until mealtime. The parallels with the exchange between Calisto and Sempronio in Aucto I are obvious: on each occasion Calisto calls for his servant, there is a brief exchange, and then Calisto asks to be left in the dark, leaving the servant standing outside his room (213-216).

Here the similarities end, however, and quite apart from the differences of context (Calisto returning home in a foul temper and abusing his servant; Calisto awakening from a short night's sleep and behaving self-indulgently), there are significant differences in the servant's response. Sempronio's well-known monologue is self- 
centred and cynical, with no evidence of any genuine concern for Calisto, about whose behaviour it contains unfavourable comments (216-217). Tristán's, on the contrary, exemplifies the apparently model servant's anxious concern to do his master's bidding, and contains no.comment at all upon his master's behaviour: 'Quiero baxarme a la puerta por que duerma mi amo sin que ninguno le impida, y a quantos le buscaren se le negaré' (489). At this point, however, Tristán's thoughts are interrupted by the din and clamour audible from the marketplace, on the cause of which he speculates.

When Sosia then comes into view, Tristán's function is extended to introduce this new character by identifying him and giving his status in the household ('De allá viene Sosia, el moço de espuelas', 489); but the scene also reinforces our impression of Tristán as model servant through his comments on the appearance and demeanour of his colleague: 'Desgreñado viene el vellaco. En alguna taverna se deve haver rebolcado, y si mi amo le cae en el rastro, mandarle ha dar dos mil palos; que, aunque es algo loco, la pena le hará cuerdo' (489-490). In dismissing it as 'toda acotación' (Estructura, 128), Stamm concentrates upon its narrative function and overlooks the importance of the monologue for what it tells us of Tristán's character, and its implications for other questions. Tristán's obvious disdain for Sosia's supposed activities not only underlines his own apparently loftier ideals; it confirms other indications which we have received concerning Calisto's exercise of his authority as master.

The reference to palos reinforces a previous aside of Calisto's ('iPalos querrá este vellaco!', 275) and suggests that the earlier reference to corporal chastisement is not a merely figurative expression of annoyance; the fact that Sosia may easily, in Tristán's mind, have been carousing in a tavern until after daybreak also adds weight to an impression - based on Calisto's exchange with Sempronio in Aucto I, on Pármeno's inability (276) to locate any servants to prepare the horse required by Calisto (an occasion on which he specifically alludes to Sosia's absence), and on his certainty that he will easily be able to pillage his master's larder and conceal the thefts (394) -- that Calisto's control over his household is generally loose and ineffective, but punctuated by outbreaks of ill-temper and the application of severe punishments. This would give added point to Pármeno's words to Areúsa (386: 'De mucha pena soy digno [...] Si voy más tarde no seré bien recebido de mi amo'), himself (387: 'Trabajo tengo con mi amo si es salido fuera'), and Sempronio (393: 
'Aun hasta en esto me ha corrido buen tiempo'), as coming from someone who is anticipating a drubbing (whether verbal or physical) and then finds that he has escaped it.

In the following messenger scene of Aucto XIII, Tristán (who, contrary to the impression given by Dunn, 122, is unaware of the executions) has the role of coaxing information out of Sosia about what the latter has witnessed in the square. It not only serves the narrative function of informing us about the fates of Pármeno and Sempronio, but is consistent with our initial judgement of relations between the two; Tristán calls Sosia 'loco' (490), and addresses him thus: 'O tú estás borracho, o has perdido el seso, o traes alguna mala nueva' (490).

The order of these conjectures is, I think, significant: Tristán evidently begins to realise that his original assumption was incorrect, and rapidly modifies it. Its inaccuracy, however, not only creates additional ironic humour in this specific episode, but also inevitably raises the question of whether Tristan's original hypothesis reflects known habits of Sosia's (remembering his earlier unexplained absence), or a prejudice against him on the part of the speaker: the disdain, perhaps, of the page for the stable-boy in a hierarchicallyorganized society, which is overcome only in circumstances where their shared condition of servitude and subordination, or a particular shared experience, gives them common ground. Once Sosia blurts out the news, however, Tristán immediately takes command of the situation and determines to awaken Calisto: not necessarily an easy decision, if the record of the latter, Sempronio's hesitation about disturbing him in Aucto I ('si entro allá, matarme ha', 216), and the references to palos are recalled (491), but one which Tristán takes with extreme rapidity.

Calisto's response is predictably negative and hostile until Sosia tells him of the situation. The ensuing soliloquy by Calisto brings the next reference to Tristán at the end of Aucto XIII (495) when his master, who has by now finally determined to continue his pursuit of Melibea undaunted by the deaths of Pármeno and Sempronio, decides to replace them with Sosia and 'Tristanico'. The only references to Tristan by name in this act, therefore, both of them uttered by Calisto, give him the diminutive suffix. In the Comedia, Tristán's next appearance follows Calisto's decision virtually immediately as Aucto XIV opens with him, Sosia and Calisto outside 
Melibea's garden the next night. Here again his role contrasts with that of one of the previous pair of servants, as various commentators have noted (e.g., Dunn, 121-2; Stamm, Estructura, 130). Whereas Pármeno, fearing lest a trap may have been laid for Calisto by Melibea, ingeniously invents plausible excuses not to comply when ordered by Calisto to go up the ladder first (458), Tristán volunteers to climb with Calisto in order to ensure that nothing untoward is awaiting the latter (499). As already noted, however, Calisto rudely rejects the offer.

The overall impression of Tristán created thus far in the Comedia is probably a favourable one, despite the problem posed by his evaluation of Sosia. While Calisto and Melibea are indulging in sexual contact, however, we see that Tristán's apparently superior standards do not extend to sexual matters, on which he is happy to share with Sosia his reactions to the events taking place in the garden. How Sosia and Tristán obtain their knowledge of these events is an unresolved problem; Tristán refers to hearing the goings-on between Calisto and Melibea ('oygo tanto'), but there is also a reference to sight ('Veslos a ellos alegres y abraçados', 502), which, if taken literally, would imply that the servants have some means of observing events (the ladder?). It is impossible to decide whether a figurative or a literal reading of 'Veslos' is more appropriate, but there are important indications of Tristán's sexuality. His comment that 'Oygo tanto, que juzgo a mi amo por el más bienaventurado hombre que nasció. $Y$, por mi vida, que, aunque soy muchacho, que diesse tan buena cuenta como mi amo' (502) could perhaps be taken to support the view expressed by some critics that we have here an equivalent to Pármeno in the sense that Tristán is thus far uncorrupted - but is, it seems, potentially corruptible. ${ }^{12}$

On the other hand, there is a distinct possibility that this may be a self-assessment informed by experience, rather than representing mere adolescent braggadocio. ${ }^{13}$ Whilst it is not clear quite what kind of relationship is implied by Lucrecia's addressing Tristán as 'mi amor' (576) slightly later in Aucto XIV of the Comedia when she is trying to ascertain what has happened to Calisto outside the garden, it does obviously indicate some unexplained previous acquaintance between them, as has been noted by previous commentators (e.g., Stamm, Estructura, 133): this is, after all, the first occasion on which Tristán has gone to the garden with Calisto, and nobody has mentioned his existence to Lucrecia at any point in the text. Unless 
it is taken as merely a sociable expression of regard for someone whom she vaguely knows (an interpretation which seems to me unlikely, and which would need to be supported with other contemporary examples), or as an expression of unilateral desire on the part of Lucrecia, this seemingly rather affectionate mode of address at least raises the possibility that Tristán, too, has experienced an amorous liaison while off duty. This must cast some retrospective doubt upon the impression of moral rectitude which he initially created. Doubt is also, of course, sown by his comments to Sosia on the nature of life as a servant, in which his relations with his master are also revealed to be far from idealistic, despite his previous faithful service outside the bedroom door, his rather superior comments upon what he assumes to have been Sosia's behaviour, and his assiduous attentions in the matter of climbing the ladder; the acid comments he makes to Sosia on the fate of Pármeno and Sempronio are worthy of note:

Ya los tiene olvidados. ¡Dexaos morir sirviendo a ruines! ¡Hazed locuras en confiança de su defension! 'Viviendo con el conde, que no matase al hombre', me dava mi madre por consejo. Veslos a ellos alegres y abraçados $y$ sus servidores con harta mengua degollados. (502)

This contains an explicit evaluation of Calisto by Tristán as ruin: an important point, as previous critics have noted, since it aligns Tristán with the views of their master expressed by Sempronio and by the corrupted Pármeno.

When events in the garden have reached their climax, and Calisto takes his departure, Tristán again assumes the role of our source of information on happenings offstage, with his lament that Calisto has fallen to his death. Here we revert to the loyal servant syndrome both in his lamentations ( ${ }^{\circ} \mathrm{O}$ mi señor y mi bien muerto! ¡O mi señor y nuestra honrra despeñado!', 575) and in his comments to Lucrecia ('iLloro mi gran mal, lloro mis muchos dolores!') and Sosia ('Llevemos el cuerpo de nuestro querido amo donde no padezca su honrra detrimento', 576). We should perhaps also note that it is Tristán who takes command in the removal of Calisto's body from outside the garden, and he who gives instructions to Sosia, thereby reverting to the role of decisive and determined taker of initiatives in which we previously saw him both on receipt of Sosia's tragic news 
and on arrival at the garden: an aspect singled out for comment by Russell.

Essentially, then, in the Comedia Tristan is a somewhat ambiguous figure. At the outset, we begin to perceive what seems to be a deliberately-wrought contrast with Sempronio, and a moral stance akin to that of Pármeno emerges when Tristán comments upon Sosia in a tone which recalls, to some extent, Pármeno's comments upon Sempronio earlier in the text $(254,261)$. Tristán is clearly the dominant element in this second pair of servants, despite the possibility that he may be the younger of the two (though Dunn, 121, seems to imply that he may be the older); his general dominance is not diminished by the fact that on one occasion Sosia tells him where to put the ladder. It is also interesting that, like Pármeno, Tristán refers to his mother; for Tristán, however, she is a source of effective and valuable advice which he remembers in the appropriate circumstances: a contrast with Pármeno's perspective upon his mother (at least, once Celestina gets to work upon it). ${ }^{14}$ But a contrast with the corrupted Pármeno emerges when Tristán offers to climb the ladder, so that Tristán cannot be seen simply as a Pármeno-substitute: at some points he resembles Pármeno, and at others he contrasts with him, and the same is true when he is compared with Sempronio in role, situation, function, and character.

Once Calisto is in the garden, however, some revision is forced upon our perceptions by the conversation between Sosia and Tristán on the relationships between masters and servants and upon sexual matters, as it is also by the mode of address used by Lucrecia, with its possible implications for the background to Tristan's comments on his own sexual performance were he, and not Calisto, with Melibea. The significance of a possible amorous relationship with Lucrecia would vary in inverse proportion to the age assigned to Tristán, from an indication of corruption of minors in the society of Celestina at one extreme to an ordinary adolescent relationship at the other. On another level, his comments on the master-servant relationship suggest a deep cynicism in the young servant. Tristán's role in the Comedia is not, therefore, a simple matter, and he is not as minor a character are might at first sight appear to be the case; he is, in fact, a further instance of the ambiguity which pervades the work, and illustrates the technique so effectively employed in the text of first establishing a character in whom readers may perceive a moral 
viewpoint with which they can identify and then creating sufficient doubt or ambiguity to undermine any such identification.

In the Tragicomedia, whilst there is much continuity in his depiction and functions (e.g. an effective humbling of Sosia and shattering of his illusions, 563), there are certain changes to Tristán. His youth is more strongly underlined, when he himself refers to his 'tierna edad' (563), when Sosia also alludes to his age in a manner which implies youth ('mucho más has dicho que tu edad demanda', 565), and when Calisto refers to him as a 'pajezico' (573). He is also, however, much more of a puer senex, inasmuch as not only does he display (as Russell notes, 516: note 75b) a medical knowledge of sleep and emotion when accounting for Calisto's staying long abed, but it is he who acutely penetrates the motives of Areúsa in inviting Sosia to visit her (much to Sosia's admiration, 565), and begins at once to plan a counter-stroke ('ármale trato doble, qual yo te diré', 564). As Shipley notes: 'As Rojas' irony would have it, there follows this diffident preamble (which claims little authority and possesses no persuasive force) as accurate a reading of the facts of the matter and the motives of the players as we encounter in all La Celestina. ${ }^{15}$

The irony is that it is all too late, as Shipley notes: they are already at the garden and are promptly hushed by Calisto, so that Tristán's perception is not acted upon (a lost opportunity, perhaps, for a further sixteenth-century continuation in the manner of the Auto de Traso). His perspicacity is nothing new; it had already been established in the Comedia by his penetrating comments upon the master-servant relationship. It should not, however, be overstated; we have seen in the Comedia his inaccurate assessment of the reasons for Sosia's dishevelled appearance, and his comments on what is in Calisto's mind are pure speculation -- but speculation which, by its seemingly authoritative medical content, may possibly be designed to impress Sosia. ${ }^{16}$ Tristán's comment 'Otro seso más maduro que el mío' before proceeding to demolish Sosia's dreams could be seen as an awareness of his own limitations -- something which we have not previously associated with Tristán; it may, on the other hand, be an ironic modesty topos employed to emphasize his own superiority over Sosia. The latter, whilst addressing him as 'hermano Tristán' (562), seems dependent upon him for approbation. Dunn (122) considers Tristán's handling of Sosia in this episode to be 'firm and tactful', but to me it seems brutally frank, and another instance of the 
'tonillo arrogante' which Lida de Malkiel (615) sees in his dealings with his companion.

The hint at a relationship between Tristán and Lucrecia posed in the Comedia is retained in the Tragicomedia, but the question is rendered more complex by the fact that in the Tragicomedia Lucrecia specifically refers to Calisto's servants never having taken any initiative with her ('Pero también me lo haría yo, si estos necios de sus criados me fablassen entre día; pero esperan que los tengo de yr a buscar', 572). This would, of course, reinforce the interpretation, in this version at least, of her earlier affectionate vocative as an expression of desire on her part rather than as evidence of an established relationship.

If we take Tristán's diminutive as indicating relative youth (as the other references to him suggest is reasonable) rather than small stature, household status, or any particular affection in which he is held by Calisto, it is a source of further important literary conclusions in the Tragicomedia. Calisto regards him as ineffectual in support of Sosia, and rushes to their assistance: 'No le maten, que no está sino un pajezico con él' (573). Whatever the actual motivation for this unprecedented action by Calisto (a sudden urge to show off in front of Melibea, or awareness of the vulnerability of his situation after the loss of Pármeno and Sempronio, might seem more likely explanations than an onset of genuine concern for his servants, unless we assume that Calisto has suddenly recovered from the mental affliction caused by love and is now for the first time revealing his real nature), its stated reason is Tristán's inadequacy in the imagined danger. This precipitate intervention is, however, unnecessary: Sosia and Tristán are his most effective retainers, and the contrasts with Pármeno and Sempronio are surely deliberately drawn.

Pármeno and Sempronio are praised to Melibea by Calisto as doughty fighters and reliable companions at the very moment when we have just witnessed their cowardice and flight in the face of an imagined threat to their persons (469-472); because of his fears of a trap, moreover, Pármeno refuses to go up the ladder first when ordered to do so by Calisto (458). Tristán, on the other hand, offers to ascend first and is peremptorily refused by Calisto. Let us recall also Tristán's general dominance over Sosia, which we see from the very first scene in which they are both involved, when he coaxes the information about the deaths of Pármeno and Sempronio from the 
distraught stable-lad. Tristán therefore serves as a further illustration of the ineptitude of Calisto's judgements of people; this did not emerge clearly in connection with him in the Comedia, but is pointedly shown in the Tragicomedia. His function has thus expanded in this respect in the final version of the text.

The humorous dimension of the scene outside the garden must not be overlooked either. Stamm explicitly rejects the idea of any humour here (Estructura, 172): 'Tristán y Sosia, suplentes en este nuevo menester, son precisamente los fieles guardaespaldas que fingían ser los anteriores, lo cual sirve para obviar cualquier toque de comicidad a este punto'. It is, however, surely the case that Calisto's woefully inaccurate judgement -- of both the seriousness of the situation (a reversal, again, of the previous occasion, where Pármeno and Sempronio, having fled at no real danger and having been praised by Calisto to Melibea, have to urgently summon him when real danger threatens) and the reliability of his servants -- is a potent source of the black, ironic humour which is so important in the work. (Compare the ironic humour of the incorrect interpretation of Sosia's appearance by Tristán in Act XIII.) This is not, of course, the only point at which Sosia and Tristán contribute to a humorous note in the added Tragicomedia material: the stupidity of the former and the reproaches of the latter upon returning home (504-505) are, as Stamm notes, 'un tipo de comedia verbal' (Estructura, 157): though again there is a serious point, since it is Tristán who sees the risk posed by Sosia's loud-mouthed revelations. The latter's opening remark to Tristán at the beginning of Act XIX on the next visit to the garden (562) returns to this point, stressing how quietly they must speak, necessary as narrative information for the reader, but again revealing their destination. On this occasion, however, Tristán does not reproach him. ${ }^{17}$

Other aspects of Tristán require comment. His use of language has been singled out by Lida de Malkiel as indicating his intellectual qualities: 'la sutileza intelectual de Tristán se expresa estilísticamente en frecuente artificio literario, por ejemplo en la rima que remata su citada observación sobre el olvido de Calisto [...] y en las antítesis con que abruma a Sosia [...] y en particular en la breve endecha paralelística a la muerte de Calisto' $(615-6)$. His name has been seen as semantically significant because of his role in discovering Calisto's broken body and lamenting his death (Russell, 96), presumably because of association with 'triste' ${ }^{18}$ The most 
elaborate exploration of the point about the association of the name with sadness is undoubtedly that of Fernando Cantalapiedra. Noting that Rojas owned a copy of a version of the Tristán story at his death in 1541, he expounds in detail the associations of the character and the indeed the very christening of Tristan with sadness and death in the Arthurian legends, and suggests a similar role for him in Celestina, concluding that 'el propio nombre evoca, y más aún en aquella época, el final trágico de Tristán e Iseo, y sirve de preparación narrativa a la muerte de Calisto y Melibea'. ${ }^{19}$ (Cantalapiedra's other arguments about the name are concerned with using it to bolster his theory of a change of authorship after the first twelve acts, and do not concern us here.)Other critics, including Russell (96), note that the name is of literary origin. ${ }^{20}$

The association with sadness is a possible, but not a necessary, conclusion; this is merely one part of his role in the text, and other associations of the name may well be of greater importance. Whilst a directly literary inspiration cannot be ruled out, in terms of the reception of the work the overtones of the name will obviously have varied from reader to reader. It is, for instance, necessary to balance the weight of literary associations with the fact that 'Tristán' was quite well known as a contemporary personal name. Only by examining its distribution, both social and geographical, in late mediaeval and early modern Spain can we hope to approach an understanding of what the name of Calisto's servant might have signified for an early reader of Celestina: whether it would have appeared modishly literary, archaic, exotic, commonplace, regional, particularly appropriate or comically inappropriate to an individual of this status. No full investigation of this question has yet been made.

A study published by Isabel Beceiro Pita draws attention to some important questions surrounding the use of the name 'Tristán' in Spain in the later Middle Ages. ${ }^{21}$ Unfortunately Beceiro Pita does not include a catalogue of the individuals whom she located, but her study of sources including the Registro General del Sello produced 114 occurrences of literary names from the mid-13th century to the mid16th century, of which one half are of 'Tristan'; this name is also the commonest in Portugal and it is the most widespread geographically (331). Her first cases of this name are Tristán Valdés, c. 1350 (326), and Tristán de Leguizamón, 1380 (330); she detects an increase in the use of literary names as the period progresses. Beceiro notes the 
existence of a converted rabbi Tristán Bogado and a murderer (homiciano) Tristán Ortiz (332), but observes that the literary names are often associated with the households of the nobility, royal administration, or urban oligarchies; she states that 'le rapport entre prénom arthurien et condition de serviteur ou d'officier apparaissait si marquée que Fernando de Rojas [...] appela l'un des serviteurs du héros Tristán' (332).

Beceiro Pita's study may, however, understate the distribution of literary names in late medieval and early modern Spain. Before my attention was drawn to it, I had already delivered a conference paper in which I pointed out, with a catalogue of literary anthroponyms, the importance of the Registro General del Sello as a source of onomastic information. ${ }^{22}$ Some further cases have since been added from other late 15th and early 16th century documentary sources, to give a sample chronologically focussed on four decades around the first printed publication of Celestina. ${ }^{23}$ The resulting corpus of literary names is given below as Appendices I-II. It will be noted that while Beceiro Pita's survey, which covers three centuries, records only five cases of 'Leonís' (331), my sample covering around four decades contains eight (Appendix II); 'half' her total sample $(=57 ?)$ consisted of cases of 'Tristán', while in my shorter period there are around fifty-three cases as a forename and twenty-one as a byname.

To draw conclusions from an incomplete survey is hazardous, since the particular selection of documentary sources used will materially affect the sample; my conclusions will remain, therefore, general, and my catalogue of names is offered as a starting point rather than a definitive statement. As will be seen from Appendix I, occurrences of 'Tristán' cover a very wide area of the Peninsula and as wide a range of social groups. For the purposes of the present paper, the catalogue lists only historical individuals attested by contemporary documentation, and ignores references to the literary character Tristán; these, which appear first in the Peninsula in the second half of the twelfth century with troubadour poems, do not bear directly upon the question of the distribution of the name in Spanish society in the era of Celestina. 'Tristán' is the commonest of all the literary names encountered in this sample, which confirms Beceiro's conclusions on this point; the relative paucity of other literary names is amply attested by the list in Appendix II. ${ }^{24}$ 
The actual number of documented individuals bearing literary names is still very small in relation to the total population, but it is becoming clear that they were more widely distributed than has perhaps been realized. Given this relatively widespread contemporary use, 'Tristán' may not, then necessarily have been a name whose literary overtones would have been dominant for either the author or the earliest readers, though they are obviously an important potential level of additional meaning. As is so often the case in Celestina, even the significance of the name is ambiguous and uncertain.

Whilst he is admittedly a secondary character if his role in considered in purely quantitative terms, Tristán nonetheless cannot be so easily dismissed as has been occasionally assumed. In the Comedia, he provides narrative information through the acotacion in his remarks, and is a source of humour; but, more importantly, in terms of his structural significance, he represents a further example of the technique of destabilisation and disorientation perpetrated in the text by introducing a character who appears to have lofty ethical standards, but about whom doubt is soon created. The subsequent re-evaluation of Tristán is the more important because of his apparent youth, which makes him a potentially telling indicator of the extent of corruption and cynicism in his society. In the Tragicomedia, however, his role is more significant even than this; if Calisto's excuse to rush to his aid is taken at face value (and it is at least consistent with his use of the diminutive not only for Tristán's name but also for his station, pajezico), there is some force to the argument that Tristán's presence outside the garden is a major contributory factor in precipitating Calisto's death in this version of the text (as Lida de Malkiel notes, 'ese menudo detalle incide en la acción', 614). Tristán, in these circumstances, approaches the level of significance earlier associated with Pármeno and Sempronio. Above all, in this way in the final canonical state of the work the culminating moment of the irony and reversal which is so consistent in Celestina is directly associated with him. 


\section{APPENDIX I}

\section{Catalogue of Individuals named 'Tristán' in selected documentary sources, $1475-1513$}

The references are to the date, plus item or page number in the source cited (for which see note 23). Individuals are identified where possible by specific details of status, office, or locality of residence. Whilst I have attempted to group multiple references to the same individual under a single entry, sufficient details are not always given by the sources to enable this to be done; as a result, there may be some duplications in this list. The converse may also be true; no. I.A22, for instance, may represent three separate individuals. Entries are in chronological order of first documented reference.

\section{A. 'Tristán' as a Christian Name}

1. Tristán de Leguizamo [Leguizamón] (27.4.1475: RGS, I, no. 462); 29.6.1475 (RGS, I, no. 533), named armador mayor of the fleet; 1.7.1475 (RGS, I, no. 535), named preboste of the town of Barrazunaga; 8.8.1475 (RGS, I, no. 608); vecino de Bilbao (4.10.1477: RGS, I, no. 2812). Numerous subsequent references in later volumes are not listed here; but note also Tristán Díaz de Leguizamo preboste de Bilbao (18.8.1490: RGS, VII, no. 2749; 9.12.1493: RGS, X, no. 3179); merced to Tristán de Leguizamo, el mozo, por muerte de su padre (22.5.1499: RGS, XVI, no. 833; cf. also nos. 974, 993, 994); and Tristán Díaz de 'Laquiza' vecino de Bilbao (13.4.1485: RGS, IV, no. 702). There is a problem with the repeated use of 'Tristán' as a forename by different members of this family, as reported by AvalleArce. $^{25}$

2. Tristán Daza supporter of the Portuguese party whose rentas in Gozón are confiscated (18.9.1475: RGS, I, no. 660); pardoned (20.3.1477: RGS, I, no. 2065); Tristán de Aza built a fortress about 22 years previously in Melgar de Yuso (13.12.1493: RGS, $X$, no. 3216)

3. Tristán Palomeque vecino de Salamanca (20.12.1475: RGS, I, no. 830)

4. Tristán de Salazar would-be rapist assaulted by servants and sons of his intended victim, his aunt (19.3.1476: RGS, I, no. 992)

5. Tristán de Silva (13.2.1477: RGS, I, no. 1800)

6. Tristán de Arauso regidor of Ecija (25.5.1478: RGS, II, no. 593) 
7. Tristán Barma [?] (2.8.1479: RGS, II, no. 1758)

8. Tristán de Espinosa (13.12.1480: RGS, III, no. 920; 9.8.1487: RGS, $V$, nos 827, 828); vecino de Cespedosa (14.4.1496: RGS, XIII, no. 563)

9. Tristán vecino de Rabe (Medina del Campo), repostero de cámara de SS. AA. (10.10.1483: RGS, III, no. 1431)

10. Tristán de Medina bachiller (26.10.1484 and subsequently: Beinart, I, 422, 427-28, 439-40, 451-52, 464-65, 476 (el bachiller Francisco Tristán de Medina), 477); Dr, inquisitor (29.5.1488: $R G S, \mathrm{~V}$, no. 3066)

11. Tristán de las Casas alcaide de Osuna (27.10.1484: RGS, III, no. 3622)

12. Tristán Holguín vecino de Medellín (22.2.1485: RGS, IV, no. 382); Tristán Holgin, killed by Miguel Dávalos of Medellín before October 1499 (2.10.1499: RGS, XVI, no. 2159); see also no. 49 below

13. Tristán de Villareal (15.4.1485, 23.4.1485: $R G S, I V$, nos 744,852$)$; Tristán de Villaherrael (5.2.1487: RGS, V, no. 67)

14. Tristán Vázquez regidor of Bayona de Miño (deceased before 17.6.1485: RGS, IV, no. 1199)

15. Tristán de Silva of Córdoba? (18.6.1485: $R G S, I V$, no. 1202)

16. Tristán Redondo runaway husband of the sister of a canon of Cuenca (2.3.1486: RGS, IV, no. 2505)

17. Tristán de Machileón pillaged the valley of Arana together with the merino of Estella (1.2.1488: RGS, V, no. 2456)

18. Tristán de Guevara (22.1.1489: RGS, VI, no. 205); vecino de Tormantos (23.3.1492: $R G S, \mathrm{IX}$, no. 933)

19. Tristán de Molina (14.3.1489: RGS, VI, no. 880); vecino de Castillo de Garcimuñoz (16.1.1495: RGS, XII, no. 175)

20. Tristán de Valdés (9.5.1489: RGS, VI, no. 1313); of Carreño, Asturias (7.4.1490: RGS, VII, no. 1255)

21. Tristán de Quesada bonesetter (2.12.1489: RGS, VI, no. 3464); vecino de Sevilla, maestro de álgebra and bonesetter (15.8.1490: RGS, VII, nos 2678, 2679); bonesetter (18.2.1495: RGS, XII, no. 700)

22. Tristán del Castillo vecino de Villanueva de Barcarrota, debtor (11.2.1490: RGS, VII, no. 323); in other documents Tristán de Castillejo vecino de Barcarrota (n.d.10.1491: RGS, VIII, nos 2889, 2892); Tristán de Castillo (26.8.1492: RGS, IX, no. 2765); Tristán de Castillejo (10.9.1493: $R G S, \mathrm{X}$, no. 2443); Tristán de Castillejo vecino de Jérez de la Frontera (7.9.1493: RGS, X, no. 
2429); Tristán del Castillo merino de Candemuñó (21.10.1496: RGS, XIII, no. 1980)

23. Tristán Ortiz vecino de Sevilla, homiciano (18.5.1490: RGS, VII, no. 1677)

24. Tristán Cruzado vecino de Almansa (19.6.1490: RGS, VII, no. 1885)

25. Tristán de Silva debtor (19.8.1490: RGS, VII, no. 2755)

26. Tristán de Silva corregidor de Madrid (26.8.1490: RGS, VII, no. 2824; in 1491: RGS, VIII, nos 15, 73, 139, 635, 1132, 2253, 2301, and as ex-corregidor, no. 2860; 3167; in 1492: RGS, IX, nos 216, 1340, 1956, 2445; in 1493: $R G S, X$, nos 1346, 2744)

27. Tristán de Cepeda vecino de Zamora (28.8.1490: $R$ GS, VII, no. 2853)

28. Tristán de Ecija had his hand cut off for spilling a sack of wheat at the fortress of Gómara (2.3.1492: RGS, IX, no. 588)

29. Tristán de Vallos vecino de Alcaraz, pardoned for killing his wife on suspicion of adultery (25.4.1492: RGS, IX, no. 1251)

30. Tristán de Arajo/Araujo vecino de Orense (24.6.1492: $R G S$, IX, no. 2360)

31. Tristán de Zúñiga vecino de Palencia (24.11.1493: $R G S, X$, no. 3009)

32. Tristán Bogado or Govado criado del rey de Portugal (1493: Cuentas, II, 61, 126, 205, 259, 340, 410, 454, 507, 535, 569)

33. Tristán de Silva of Ciudad Rodrigo (15.2.1494: RGS, XI, no. 393)

34. Tristán de Sandoval deceased (20.2.1494: RGS, $\mathrm{XI}$, no. 481); owned property in Sotillo (28.7.1495: RGS, XII, no. 2923)

35. Tristán de Merlo vecino de Córdoba (6.3.1494: RGS, XI, no. 619)

36. Tristán de Gante (24.4.1494: RGS, XI, no. 1435)

37. Tristán de Abrojo merino mayor del conde de Monterrey, Galicia (6.5.1494: RGS, XI, no. 1737)

38. Tristán de Agramonte vecino de Alcalá de Henares, assault victim (1.10.1494: RGS, XI, no. 3020)

39. Tristán de Çaballos vecino de Camargo, Santander (n.d.11.1494: $R G S, \mathrm{XI}$, no. 4112)

40. Tristán de Arcilla (20.12.1494: $R G S, X I$, no. 4461); Tristán de Arcilla/de Arcila vecino de Aranda (22.8.1495: RGS, XII, no. 3236; 24.9.1495: RGS, XII, no. 3546).

41. Tristán de Sahagún (?1494: Burgos Carta de censo de Francisco de Lerma vicino de Burgos sobre Tristán de Sahagún y Constancia del Castillo su muger: Moorat, Catalogue, pp. 1468-69, no. 802[7]); vecino de Burgos (9.9.1499: RGS, XVI, no. 1740)

42. Tristán de Domesain castellano de San Juan Pie de Puerto (31.3.1496: Suárez Fernández, IV, p. 655)

43. Tristán de Azcue (n.d.6.1497: RGS, XIV, no. 1728) 
44. Tristán de Molina caballero de la Orden de Santiago (1.3.1498: RGS, $\mathrm{XV}$, no. 501)

45. Tristán de la Peña vecino de Guadarrama y Colmenar Viejo (15.6.1498: RGS, $\mathrm{XV}$, no. 1600)

46. Tristán de Quevedo vecino de Jaén (26.7.1498: RGS, XV, no. 1831). Possibly different from Tristán de Quevedo, involved in an incident at Perpignan which was later the subject of royal attention (26.4.1499: RGS, XVI, no. 616)

47. Tristán de Ballesteros escribano de Alcaraz (23.2.1499: RGS, XVI, no. 420 )

48. Tristán de Avendaño (also Aredaño or Avedaño) vecino de Cuenca (25.5.1499: RGS, XVI, no. 880; 18.11.1499: RGS, XVI, no. 2745)

49. Tristán Holgin, son of Tristán Holgin, no. 12 above, petitioner after his father's death (2.10.1499: RGS, XVI, no. 2159)

50. Tristán de León bachiller (6.3.1505: Testamentaria, pp. 381, 385)

51. Tristán don, criado del Gran Capitán (1505: Testamentaria, p. 111)

52. Tristán escudero de pie (1505: Testamentaria, p. 443)

53. Tristán tondidor: witness in an Inquisition trial in 1513, referred to in the fullest references as Tristán, tondidor, christiano viejo, and as vezino de Ciudad Real (Beinart, II, 349, 357, 398, 400, 405, 527). Possibly to be identified with Tristán Cauallero tondidor (Beinart, III, 159, 160, 162, who is described in the fullest reference as Tristán Cavallero, vesino de Çibdad Real, tondidor, testigo jurado, etc, dixo que de hedad de quarenta años, christiano viejo (25.10.1513: 182-83; also 194, 208, 209, 212, 221); he was de edad de çinquenta años, poco mas o menos in November 1520 (Beinart, III, 225)

\section{B. 'Tristán' as a Byname}

Where 'Tristán' occurs as a byname, the likelihood is that an ancestor bore this name; in most cases it is impossible to know at what date the name was first acquired, since by the period under review it is fully transmissible (e.g., Juan Tristán son of Pedro Tristán, no. I.B18 below). Byname occurrence is still, however, an important dimension of the incidence of 'Tristán' in late medieval Spanish onomastics.

1. Catalina Tristán (4.5.1476: $R G S, \mathrm{I}$, no. 1134)

2. Francisco Tristán former secretary of Enrique IV, named escribano de Cámara (15.4.1477: RGS, I, no. 2219)

3. Juan de Tristán mayordomo of Fernando Arias de Saavedra (14.10.1477: RGS, I, no. 2834) 
4. Gonzalo Tristán (9.9.1484: RGS, III, no. 3320)

5. Juan Tristán vecino de Sevilla (1.6.1485: RGS, IV, no. 1051; 16.5.1491: RGS, VIII, no. 1554; 17.5.1491: no. 1561; 24.7.1489: RGS, VI, no. 2087); almojarife, Seville? (29.4.1491: RGS, VIII, no. 1452); vecino de Sevilla (17.1.1492: RGS, IX, no. 89; 4.2.1492: RGS, IX, no. 218; n.d.4.1492: RGS, IX, no. 1345, same as Suárez Fernández, III, 277-78: vecino e jurado de Sevilla, shipowner; 3.5.1492: RGS, IX, no. 1412; 7.5.1492: RGS, IX, no. 1482); recaudador mayor de Sevilla (18.5.1492: RGS, IX, no. 1766; 28.5.1492: RGS, IX, no. 1933; 7.11.1492: RGS, IX, no. 3249; 12.11.1492: RGS, IX, no. 3295; 2.5.1494: RGS, XI, no. 1686; 27.11.1494: $R G S, \mathrm{XI}$, no. 4028, 3.12.1494: $R G S, \mathrm{XI}$, no. 4170, 11.12.1494: RGS, XI, no. 4258; 8.1.1495: RGS, XII, no. 43); deceased (26.10.1496: RGS, XIII, no. 2022; 8-9.5.1498: RGS, XV, nos $1322,1323,1346)$

6. Martín Tristán (30.7.1487: RGS, V, no. 745; 22.8.1489: RGS, VI, no. 2477)

7. Francisco Tristán vecino de Sevilla, owned olive groves in Ecija (4.9.1487: RGS, V, no. 1154); debtor (12.9.1489: RGS, VI, no. 2736); vecino de Sevilla, debtor, reconciliado, brother of Gonzalo Tristán (no. I.B14 below; 10.5.1492: RGS, IX, no. 1539)

8. Pedro Tristán repostero de camas, owner of pinewood (15.1.1489: $R G S, \mathrm{VI}$, no. 118)

9. Lope Martínez de Tristánez vecino de un lugar del valle y tierra de Mena (10.9.1489: RGS, VI, no. 2720)

10. Juan Tristán vecino de Utrera (14.9.1489: RGS, VI, no. 2749)

11. Juan Tristán vecino de Sanlúcar, assault victim (6.7.1490: RGS, VII, no. 2077)

12. Juan Tristán of Lebrija? (15.7.1490: RGS, VII, no. 2232)

13. Juan Tristán vecino de Medina del Campo (9.4.1491: RGS, VIII, no. 1285)

14. Gonzalo Tristán vecino de Sevilla, debtor, reconciliado, brother of Francisco Tristán (no. I.B7 above; 10.5.1492: RGS, IX, no. 1539)

15. Luis Tristán arrendador y recaudador mayor de las alcabalas de Ecija 1488-1489 (5.9.1493: $R G S, \mathrm{X}$, no. 2394); possibly the same as Luis Tristán who had been arrendador de la alhóndiga de Sevilla during 1489 (8.5.1499: RGS, XVI, no. 691)

16. Pero Tristán vecino de Miruelo (and/or of Cudeyo?) 13.7.1495: RGS, XII, no. 2720)

17. Juan Tristán debtor of Ecija? (16.2.1497: RGS, XIV, no. 554)

18. Pedro Tristán, and Juan Tristán his son sentenced because of alboroto (7.3.1498: RGS, XV, no. 581); same as Pedro Tristán 
whose family were involved in a lawsuit (15.7.1499: RGS, XVI, no. 1157)

19. Diego Tristán, escribano público in Granada (28.11.1509: Bejarano, p. 101, no. 518)

20. Rodrigo Tristán mentioned in the trial of María González, 15111512 , but which includes witness statements taken as early as January 1475 (Beinart, II, 216, 219; 21.10.1513: III, 83)

21. Francisco Tristán (25.10.1513: Beinart, III, 130, 224): este Françisco Tristán no se halla en Çibdad Real; dizese que esta en Toledo 
76 DAVID HoOK

\section{APPENDIX II}

Catalogue of Other Personal Names of Literary Origin

The same sources are used as for Appendix I (see note 23); entries are in chronological order of first documented appearance. ${ }^{26}$

A. Braçaida: 4

1. Brezaida criada y mujer del Marqués de Aguilar (reign of Enrique IV: RGS, V, no. 41); same as Brazaida, muger de García Fernández Manrique (8.10.1476: RGS, I, no. 1510)

2. Braçayda de Benavides (1489-1503: Cuentas, I, 297, 403; II, 380, 415, 595 )

3. Bracida Sánchez (12.4.1494: RGS, XI, no. 1214)

4. Braçayda de Almada (13.6.1496: RGS, XIII, no. 968)

B. Briolanja: 3

1. Briolangel González (a.k.a. Briolangel de Padilla, 1483-84: Beinart, I, 81, 149, 392, 394, 396, 400, 402, 404, 408-11, 413-19, 558-59)

2. Briolanja Muñoz (24.10.1496: RGS, XIII, no. 1994)

3. Briolangel de Vera (1503: Beinart, III, 164; IV, 405)

C. Florestán: 3

1. Floresdán de Tapia (3.3.1486: RGS, IV, no. 2502)

2. Florestán (13.8.1493: $R G S, \mathrm{X}$, no. 2165)

3. Francisco Floristán (6.5.1497: RGS, XIV, no. 1268)

D. Galaor: 3

1. Galaor Osorio (deceased before 22.2.1491: RGS, VIII, nos 515, 1413, 1430; in 1497: RGS, XIV, no. 2092; in 1498: RGS, XV, nos 1795, 1894)

2. Galor Mosquera (30.6.1491: RGS, VIII, no. 1833; in 1493: RGS, X, no. 1095; in 1496: RGS, XIII, nos 2243, 2686, 2687; in 1497: RGS, XIV, no. 2635)

3. Galaor de la Carrera (8.4.1497: RGS, XIV, no. 972)

E. Galáz: 2

1. Galás de Leguizamo (16.10.1483: $R G S$, III, no. 1499)

2. Maese Galáz (1485-1503: Cuentas, I, 91; II, 57, 75, 588)

F. Galván: 8 
1. Diego Galván (24.11.1485: $R G S$, IV, no. 2008; 20.9.1498: $R G S, \mathrm{XV}$, no. 2294)

2. Juan de Galván (17.1.1488: RGS, V, no. 2058)

3. Cristóbal Galván (8.10.1488: RGS, V, no. 3990)

4. Pero Galván (n.d.2.1490: RGS, VII, no. 464); Pedro Galván (Cuentas, II, 74, 1493)

5. Aparicio de Galván (10.5.1493: $R G S, \mathrm{X}$, no. 1184; 20.9.1498: RGS, $X V$, no. 2281)

6. Antón Galván (24.7.1493: RGS, X, no. 1991)

7. Alonso Galbán (father) (9.11.1497: RGS, XIV, no. 2482)

8. Francisco Galbán (son) (9.11.1497: RGS, XIV, no. 2482)

G. Iseo: 4

1. Iseo Fernández (5.12.1487: RGS, V, no. 1745)

2. Iseo Maldonado (18.7.1492: RGS, IX, no. 2462)

3. Iseo Fajardo (12.7.1493: $R G S, \mathrm{X}$, no. 1905)

4. Iseo (1.9.1495: $R G S, X I I$, no. 3310)

H. Lanzarote: 3

1. García Lanzarote (24.3.1487: RGS, V, no. 238; 16.9.1492: RGS, IX, no. 3014)

2. Lançarote de Ameçaga (3.7.1490: Suárez Fernández, III, 198)

3. Lanzarote (28.2.1497: RGS, XIV, no. 653)

I. Leonis: 8

1. Leonís Méndez de Sotomayor (22.10.1479: RGS, II, no. 2025; 22.6.1488: RGS, V, no. 3283); Leonís Méndez (24.2.1492: RGS, IX, no. 501); Leonís Méndez de Sotomayor (in 1495: RGS, XII, no. 1145; in 1498: RGS, XV, no. 2670; in 1499: RGS, XVI, nos. $657,2596)$

2. Leonés de Noroña (23.10.1487: RGS, $\mathrm{V}$, no. 1561)

3. Leonís de Villanueva (10.10.1491: RGS, VIII, no. 2737; in 1492: RGS, IX, nos 2320, 2648, 3339, 3351)

4. Leonís (2.5.1492: RGS, IX, no. 1371)

5. Leonís/Lionel de Ribera (28.5.1492: $R G S$, IX, nos 1912, 1932)

6. Leonís de Narváez (28.2.1493: $R G S, \mathrm{X}$, nos 447, 522)

7. Pero Leonés/Pedro Leonís (7.10.1495: RGS, XII, nos 3660, 3903)

8. Leonís de Valdés (19.12.1498: RGS, $\mathrm{XV}$, no. 3010)

J. Merlín: 2

1. Pedro [Alonso] Merlín (12-14.1.1490: Trujillo, 306, 313; 6.3.1490: $344,345-6)$ 
2. Diego Merlín (n.d.1.1491: RGS, VIII, nos 264, 462)

K. Perseval: 3

1. Perseval (4.2.1478: RGS, II, no. 240)

2. Perseval de Grimaldo (7.11.1489: RGS, VI, no. 3204)

3. Perseval son of Pedro (2.9.1496: RGS, XIII, no. 1564)

(An earlier Perseual Martines, who falls outside the chronological scope of this survey, is referred to in a letter of Enrique de Villena dated 'IX kalendas junii anno xxvij' discussed by Derek C. Carr in his paper 'Neologisms in the Carta de don Enrique de Villena al Deán y Cabildo de Cuenca', IV Colloquium on XVc Literature, Queen Mary \& Westfield College, London, 3-4 July 1992)

\section{Troilo(s): 1}

1. Troilos Carrillo (28.1.1478: RGS, II, nos 184, 751, 821, 177); Troilo Carrillo (27.4.1484: $R G S$, III, no. 2721), Troilos Carrillo (1485: $R G S$, IV, no. 745,2408 ; in 1486: 2618; in 1491: RGS, VIII, no. 1473)

plebcrio. Rucrecio, ascluber.

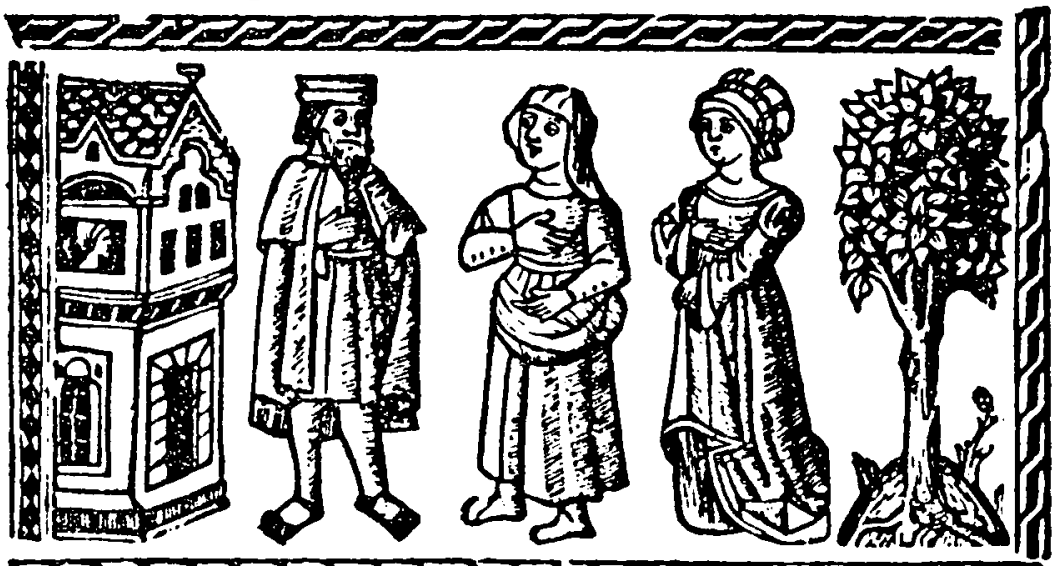

Valencia 1514. Grabado del $20^{\circ}$ aucto. 


\section{NOTES}

${ }^{1}$ Comedia o Tragicomedia de Calisto y Melibea, edited by Peter E. Russell, Clásicos Castalia, 191 (Madrid: Castalia, 1991), 96. All references are to pages of this edition, except where another specified edition is cited to clarify a textual point.

${ }^{2}$ Peter N. Dunn, Fernando de Rojas, Twayne's World Authors Series, 368 (Boston: Twayne, 1975), 121-2.

3 'People, Characters and Roles: A View of Characterization in Celestina', in Fernando de Rojas and 'Celestina': Approaching the Fifth Centenary. Proceedings of an International Conference in Commemoration of the 450th Anniversary of the Death of Fernando de Rojas (Purdue University, West Lafayette, Indiana, 21-24 March 1991), edited by Ivy A. Corfis and Joseph T. Snow (Madison: HSMS, 1993), 181-91, at 184-5.

${ }^{4}$ Celestina. Tragicomedia de Calisto y Melibea, Introducción y edición crítica de Miguel Marciales, al cuidado de Brian Dutton y Joseph $T$. Snow, Illinois Medieval Monographs, I, 2 vols (Urbana: University of Illinois Press, 1985), I, 276.

${ }^{5}$ María Rosa Lida de Malkiel, La originalidad artística de 'La Celestina', 2nd edition (Buenos Aires: EUDEBA, 1970), 614-6, at 614-

6 Comedia de Calisto $\mathcal{E}$ Melibea, ed. Jerry R. Rank, Estudios de Hispanófila, 49 (Chapel Hill, NC: Hispanófila, 1978), 191, with 'leuantate' in the main text and the reading 'leuanta' noted (239 n. 29) in two of the early Comedia editions.

7 La estructura de 'La Celestina'. Una lectura analítica, Acta Salmanticensia, Estudios Filológicos, 204 (Salamanca: Universidad de Salamanca, 1988), 128.

${ }^{8}$ A feature retained in the Tragicomedia: 504, 515, 562, 565.

9 Alfonso Martínez de Toledo, Arcipreste de Talavera, ed. Marcella Ciceri, 2 vols (Modena: STEM-Mucchi, 1975), I, 134, with my corrections of the readings Alosillo and ma. 
${ }^{10}$ Fernando González Ollé, Los sufijos diminutivos en castellano medieval, RFE Anejo LXXV (Madrid: CSIC, 1962). For the Cuentas de Gonzalo de Baeza, see note 23 below.

${ }^{11}$ Haim Beinart, Records of the Trials of the Spanish Inquisition in Cuidad Real, III, The Trials of 1512-1527 in Toledo (Jerusalem: The Israel Academy of Sciences and Humanities, 1981), 399. Further cases of servants referred to with a diminutive are encountered in the Inquisition records concerning María de Cazalla in the 1520s-1530s edited by Milagros Ortega Costa, Proceso de la Inquisición contra María de Cazalla (Madrid: Fundación Universitaria Española, 1978): 'Aguilarico, criado de Tovar' (479), 'Francisquillo su page' (518), but again with no information on their ages.

${ }^{12}$ A point noted also by Hajime Okamura, 'Lucrecia en el esquema didáctico de Celestina', Celestinesca, 15:1 (mayo 1991), 53-62, at 61-2 note 18: 'Quizá no habrá mucha distancia entre Tristán y Sosia, por una parte, y los otros tres criados, por otra. Pármeno, se sabe, se convierte en mal criado porque ha sufrido tratamientos injustos de Calisto; Tristán y Sosia siguen fieles, porque no los sufren. Pues éstos tienen la posibilidad de perjudicar a su amo en cualquier momento según posibles cambios de circunstancias.' But neither of them has, of course, spoken to Celestina, as Lida de Malkiel notes (615).

${ }^{13}$ For Alan Deyermond, 'Divisiones socio-económicas, nexos sexuales: la sociedad de Celestina', Celestinesca, 8:2 (otoño 1984), 3-10, at 7, this speech 'difiere de la reacción de Celestina frente a los encuentros eróticos de Areúsa y Pármeno, Elicia y Sempronio [...] sólo en la edad y la energía sexual de los que hablan', but this does not affect the question of Tristán's possible erotic experience.

${ }^{14}$ Although here one could ask how accurate Pármeno's account of her to Calisto in Act I actually is, and whether in fact Celestina is simply reminding him of facts he would sooner have forgotten, rather than giving him a wholly manipulated portrait of his mother totally different from, and opposed to, his own recollections, it is relevant that he states that he left her at a very young age, and that at this point in the text we have no grounds for questioning Pármeno's veracity. Russell accepts that he genuinely knew nothing of her witchcraft (241 note 143). Note also that for James R. Stamm, 'Reading and Listening in Celestina', Fernando de Rojas and 'Celestina': Approaching the Fifth Centenary, 371-81, at 380, Tristán is among the 
other figures who 'do not function as personae given primary access either to oral or literary authority, although the odd dicho will appear from time to time'. This, however, obscures the contrast between Pármeno's relationship to his mother once Celestina has manipulated it (a problem) and Tristán's (a source of help).

${ }^{15}$ George A. Shipley, 'Authority and Experience in La Celestina', BHS, 62 (1985), 95-111, at 99.

${ }^{16}$ Marciales considers Tristán's explanation of Calisto's state of mind a problem ( $I, 135)$ in view of its dependence on information which cannot have been available to the servants. If one concentrates rather on the medical dimension of the explanation, Tristan's observation can be seen as an intelligent guess, on the motivation of which one may legitimately speculate.

${ }^{17}$ Are they speaking softly (Sosia having taking the previous occasion to heart), or is Tristán too concerned with the content of Sosia's revelations to worry about the conversation being overheard? No doubt in some quarters this point of difference between the two incidents would be seen as evidence for a difference of authorship in the two passages involved.

18 If a further footnote may here be added to this approach, it is curious that Tristán thrice uses the word 'triste' in the Comedia, and that on each occasion it is followed by a noun or adjective with an initial nasal (tristes nuevas, 491; triste muerte, 575; triste y nueva, 576). These juxtapositions may suggest that an element of verbal patterning is associated with the name of the character (cf. the final nasal of 'Tristán'), though it is equally uncertain whether much weight should be attached to this, and what its significance might be. The same pattern is observable in a remark he makes in the Tragicomedia additions (el triste de nuestro amo, 575).

19 'Evocaciones en torno a los nombres de Sosia y Tristán', Celestinesca, 14:1 (mayo 1990), 41-55, at 44-7. For Rojas's copy of the book in 1541, see Stephen Gilman, The Spain of Fernando de Rojas. The Intellectual and Social Landscape of 'La Celestina' (Princeton: Princeton University Press, 1972), 439. 
${ }^{20}$ It had been noted also by Julio Cejador, 'nombre tomado de la leyenda conocida del ciclo bretón': La Celestina (Madrid: Ediciones de La Lectura, 1913), II, 114 n.15.

${ }^{21}$ Isabel Beceiro Pita, 'La fascination pour la "matière de Bretagne" dans la noblesse castillane du Moyen Age tardif', in La Bretagne, terre d'Europe (Brest: Centre de recherche bretonne et celtique, and Quimper: Société archéologique du Finistère, 1992), 325-34. I am grateful to Dr Peter Linehan, who kindly told me of the existence of this item in May 1993 and furnished me with a copy of it. Beceiro's study does not, however, adequately cover the earliest phase of Arthurian material in the Peninsula, for which see my The Earliest Arthurian Names in Spain and Portugal, Fontaine Notre Dame., I (St Albans: David Hook, 1991), and 'Further Early Arthurian Names from Spain', La Corónica, 21.2 (1992-93), 23-33.

22 'Documentary Mentions of Literary Characters', IV Colloquium on XVc Literature, Medieval Hispanic Research Seminar, Queen Mary and Westfield College, London, 25 September 1992. The paper was accompanied by a printed list of 'Documentary References to Individual Homonyms of Literary Characters', distributed as a handout. The sixteen volumes thus far published of the Registro cover the period to December 1499; more than 58,000 documents are calendared, and each volume has an onomastic index. Further literary names will require collection from future volumes in the series.

${ }^{23}$ Sources used are as follows:

Beinart: Haim Beinart, Records of the Trials of the Spanish Inquisition in Ciudad Real, 4 vols (Jerusalem: The Israel Academy of Sciences and Humanities, 1974-1985). References are to volume and page.

Bejarano: Francisco Bejarano, Catálogo de los documentos del reinado de los Reyes Católicos existentes en el Archivo Municipal de Málaga, Biblioteca Reyes Católicos, Inventarios y Catálogos, VIII (Madrid: CSIC, 1961). References are to page and item number.

Cuentas: Antonio de la Torre and E.A. de la Torre, Cuentas de Gonzalo de Baeza, tesorero de Isabel la Católica, 2 vols, Biblioteca Reyes Católicos, Documentos y Textos, V-VI (Madrid: CSIC, 195556). References are to volume and page. 
Moorat, Catalogue: S.A. J. Moorat, Catalogue of Western Manuscripts on Medicine and Science in the Wellcome Historical Medical Library, II: MSS Written after 1650 A.D., Publications of the Wellcome Institute of the History of Medicine, Catalogue Series, MS 3 (London: The Wellcome Institute of the History of Medicine, 1973); the volume for $\mathrm{N}-\mathrm{Z}$ contains a Supplement with additional pre-1650 MSS.

RGS: Registro General del Sello, I-XII (Valladolid: CSIC, 1950-1974), XIII-XVI (Madrid: Ministerio de Cultura, Dirección General de Bellas Artes y Archivos, 1987-1992). References are to volume and item number. Given the size of the RGS corpus, I have used the index to each volume rather than reading all the documents as is my usual practice; all index entries noted have however been checked against the calendared documents. Any cases of the literary names studied here which are not indexed will therefore have been omitted.

Suárez Fernández: Luis Suárez Fernández, Política Internacional de Isabel la Católica, 5 vols (I: Valladolid: Instituto 'Isabel la Católica' de Historia Eclesiástica, 1965; II-V: Valladolid: Universidad de Valladolid, Departamento de Historia Medieval, 1966-72). References are to volume and page.

Testamentaria: Antonio de la Torre y del Cerro, ed., Testamentaria de Isabel la Católica, Documentos, 10 (Valladolid: Instituto 'Isabel la Católica' de Historia Eclesiástica \& CSIC, 1968)

Trujillo: Haim Beinart, Truijllo. A Jewish Community in Extremadura on the Eve of the Expulsion from Spain, Hispanica Judaica, 2 (Jerusalem: The Magnes Press/The Hebrew University, 1980).

${ }^{24}$ The 53 or so occurrences of Tristán as a forename and 21 as a byname in this corpus compare with a maximum frequency of eight cases for the commonest of the other literary names in Appendix II. The definition of a 'literary name' is, of course, problematic. For present purposes, it denotes a name which is not known to form part of the onomastic resources of the Iberian Peninsula previous to its appearance as the name of a character in a literary work. Thus Arthurian names such as Galván and Artüs do not seem to have been known in the Peninsula before the twelfth century, but thereafter are documented with increasing frequency; names of characters in Amadis de Gaula occur in advance of the earliest known printed edition, indicating manuscript diffusion (e.g., Harvey L. Sharrer, 'Briolanja as a Name in Early Fifteenth-century Portugal: echo of a reworked Portuguese Amadís de Gaula?', La Corónica, 19:1 (1990-91), 112-18; for 
a further problem with Amadís, see my '"Esplandian" (Logroño, 1294) and the Amadis Question', Journal of Hispanic Research, 1 (1992-93), 2734). Among problems associated with the concept of 'literary names' is the fact that a name may become so well established that social imitation or family tradition rather than direct literary inspiration accounts for its continuing use as a forename (as in the case of the Leguizamón family recorded by Avalle-Arce, note 25 below); and that it may have multiple literary occurrences (e.g., the presence of Galván as a name in ballads, removed from its Arthurian origins; the references to Iseo, Tristán and Lanzarote in Amadis de Gaula, a work in which Leonis appears as a personal name, possibly based on the toponym Lyonesse in Arthurian tradition (cf. Tristán de Leonís); and the re-use of Braçaida from the Troy story in Juan de Flores's Grisel y Mirabella). One would also need to consider whether a form such as Briolangel (deriving from Briolanja by popular etymology or deliberate religious adaptation?) would constitute a 'literary name'. It is also necessary to distinguish between the active use of a literary forename and its eventual fossilisation as a byname, since this distinction must be taken into account for chronological reasons and in assessing, so far as the evidence will permit it, the changing popularity of particular literary forenames. In this sample, for instance, 'Galván' does not appear in current use as a forename, and is registered only as a transmissible byname: cf. Appendix II, nos F78. In earlier periods, 'Galván' outnumbers all other Arthurian names encountered (see my The Earliest Arthurian Names and 'Further Early Arthurian Names', note 21 above).

${ }^{25}$ Juan Bautista Avalle-Arce, 'Onomástica épico-caballeresca en la Vasconia medieval', in The Two Hesperias. Literary Studies in honor of Joseph G. Fucilla on the occasion of his 80th Birthday, edited by Americo Bugliani, Studia Humanitatis (Madrid: José Porrúa Turanzas, 1977), 41-53.

${ }^{26}$ I am grateful to Professor Alan Deyermond for the loan of an elusive bibliographical item, and to Professor Vivian Nutton for assistance with material at the Wellcome Institute. 